\title{
Competence-driven engineering education: A case for T-shaped engineers and teachers
}

\author{
Alabadan Babatope A ${ }^{1}$, Taiwo M. Samuel ${ }^{2}$, Philip I. Ajewole ${ }^{3}$, Oluwakemi M. Anyanwu ${ }^{4}$ \\ ${ }^{1}$ Department of Agricultural and Bioresources Engineering, Federal University, Nigeria \\ ${ }^{2}$ Department of Agricultural and Mechanical Engineering, Olabisi Onabanjo University, Nigeria \\ ${ }^{3,4}$ Department of Educational Management, Federal University, Nigeria
}

\begin{tabular}{l} 
Article Info \\
\hline Article history: \\
Received Aug 5, 2019 \\
Revised Oct1 6, 2019 \\
Accepted Feb 27, 2020 \\
\hline
\end{tabular}

\section{Keywords:}

Education

Engineering

Graduates

Skills

T-shaped

\begin{abstract}
The demand for engineering education and graduates is increasing daily because the current service and technological designs are unable to meet the needs of the society and the expected dramatic increase in the future. The emerging skill gap requires a shift in the type of expertise required of young professionals that will be needed to successfully lead organizations in the new economy. Researchers have identified various 'shapes' for the engineering professionals to make them relevant to the $21^{\text {st }}$ century challenge, especially in the industry where their expertise is much needed. $\mathrm{T}$-shaped professionals have skills that make them to be more preferred among others. The purpose of this paper is to present the need to upgrade engineering education curriculum to produce more $\mathrm{T}$-shaped graduate engineers required in the changing industrial world. The potential benefits of $\mathrm{T}$-shaped professionals to organizational performance are quite significant; hence, the demand for T-shaped professionals in knowledge-intensive, service-oriented economies is increasing. Unfortunately, the challenges associated with creating more T-shaped professionals are also significant. National regulatory bodies for engineering education in Nigeria are beginning to move towards integrated curriculum to break down discipline silos and produce T-shaped graduate engineers for the fast-changing industrial world. Service Science Management and Engineering (SSME) is an emerging discipline with over 250 programmes in 50 nations seeking to create more T-shaped professionals.
\end{abstract}

This is an open access article under the CC BY-SA license.

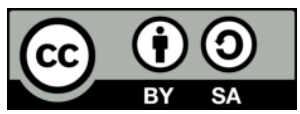

\section{Corresponding Author:}

Alabadan Babatope A

Department of Agricultural and Bioresources Engineering,

Faculty of Engineering,

Federal University, Oye Ekiti,

(IKOLE-EKITI CAMPUS), Nigeria.

Email: babatope.alabadan@fuoye.edu.ng

\section{INTRODUCTION}

Organizations are facing conditions of growing complexity that challenge decision-making, innovative activities and increasing need to develop dynamic capabilities in the ever-changing environment [1]. Peters [2] identified that a new design would either leads towards a career as a specialist or as a generalist. Why not a two-track system of design education?

Human resources managers are in dire need of new workers or graduates with strong technical skills, adept at written and verbal communication, understand how to get things done in a complex, fastmoving organization, and who can be depended upon to interact positively with co-workers, partners and 
customers. Technological companies seeking a competitive edge increasingly seek for employees embodied with these "soft" skills [3].

Dash-shaped skilled people have some knowledge about everything. They are generalists who also provide low value added. The I-shaped skilled people are good at something, particularly since there is more value added. A combination of Dash-shaped and I-shaped skills in the team gives a really powerful combination. However, complex problems that are more difficult to solve in the business world require interdisciplinary teams since they provide the most value addition not available in an individual [4].

The term "T-shaped" is not new: it has been in use since the 1990s, mostly in consulting and technical fields. The idea of T-shaped skills was first mentioned by Guest [5] in an article discussing the future of computer jobs. Today, T-shaped skills are a razor that can cut through all the complexity in the more and more complex world [5].

The concept of T-shaped skills described the attributes of desirable workers. The T-shaped individual is a professional having both depth and breadth of knowledge as shown in Figure 1. The vertical bar of the ' $\mathrm{T}$ ' depicts a deep understading of a particular technical area or discipline while the horizontal bar of the ' $\mathrm{T}$ ' shows ability and willingness to share the knowledge acquired in areas of expertise with professionals in other disciplines rather than in one's narrowed discipline [5].

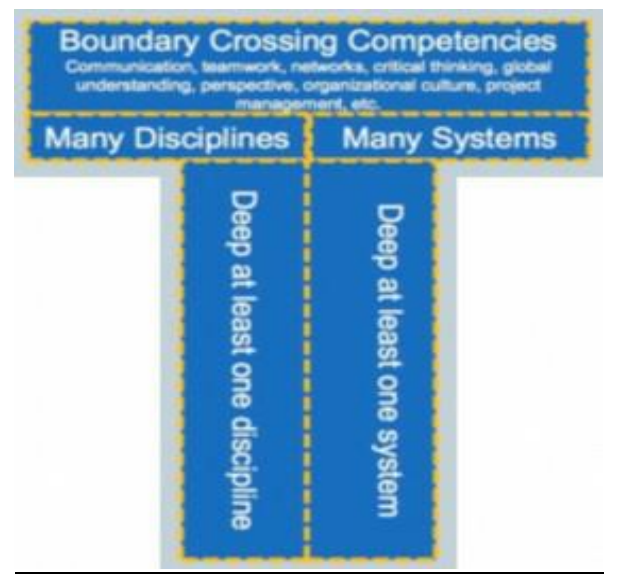

Figure 1. T-shaped graduates needs [5]

Leading companies and enterprises look for work-ready graduate engineers that are able to deal with changing customer needs, greater competition and shifting markets right at the start. Employers expect new workers both to hit the ground running and to maintain relevant new skills through lifelong learning, selfdirected and on their own pace. Industry is beset by many changes such as social, technological scientific and economic. These changes have affected all areas of life, including engineering. Consequently, the faculties of engineering in Universities have to respond appropriately to meet up with the more dynamic and faster changing industry $[6,7]$.

\section{THE T-SHAPED ENGINEER AND THE TECHNOLOGICAL REVIVAL}

Technology is currently undergoing a dramatic innovation. However, for this renewed appreciation to be a success, it is vital that the new technician is T-shaped. The engineering community agreed that the concept of $\mathrm{T}$-shaped is ideal for the training of engineering graduates for successful practice in the global economy. We can find the usefulness of the T-shaped concept everywhere and every field will require $\mathrm{T}$-shaped professional for development. The engineers are out in front on this concept $[4,8]$.

Companies employ graduates for their core technical depth. The graduate trainee programmes of most organizations devoted a lot of time and efforts on how to integrate and coach graduates to be effective in what is rapidly becoming a more team-oriented work environment. The skills needed to be impacted on the students by the engineering teachers during their five-year programme are shown in Figure 2. The total number of students needed to combine the technical expertise with the entrepreneurial and management skills is the key factors for the T-shaped engineers and teachers. The resulting engineers with entrepreneurial attitude, innovative mindset, knowledge of changing trends and leadership and management skills with deep technical skills would produce maximally [9]. 


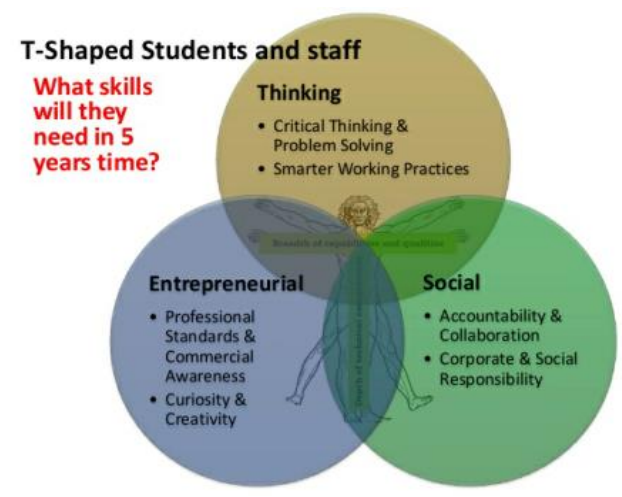

Figure 2. T-shaped students and staff [10]

\section{THE ROLE OF UNIVERSITIES IN DEVELOPING WORK-READY AND T-SHAPED PROFESSIONALS}

The Universities traditionally create professionals who specialized in one specific domain (I-shape). Universities are now expected to do more to prepare students for the job. Universities should create opportunities in their educational system through which students can develop those skills as part of their academic achievement and come out of the universities better prepared [11]. A good start is emphasizing collaborative and hands-on experiences that give students a sense of the workplace. Becoming a specialist required hard work and constant professional improvement, a task that have to be undertaken personally [3].

Engineering programme should produce the 'societal engineers' that are ready to use their T-shaped skills to change and advance the society. One response that seems to be promising is the creation of moreT-shaped professionals that used their skills as best practices to provide T-related solutions across the country. It has been proven many times that a change in technology or market conditions devalues knowledge of I-shaped professionals but T-shaped professionals on the other hand have a lot of potentials [12-14].

Since 2004, IBM has been working with Universities, governments and partnering with industries around the world to for the introduction of a new discipline called Service Science Management and Engineering (SSME). SSME seeks to address the need for increased Science Technology Engineering and Mathematics (STEM) education to meet industry's need for more research-driven service sector innovation [15]. SSME helps to createT-shaped professionals who are better collaborative innovators [7] and adaptive innovators [16].

The shift from the predominantly manufacturing based industries to the service based one is one of the many challenges the Universities are facing in equipping graduates with the right skills and attitudes that will make them employable. There is a need to examine the current curriculum and methods of instruction so as to ensure that future graduates will be suitable for this new economy. A combination of the T-shaped concept and the newly developed field of Service Science, Management and Engineering (SSME) approaches should be use to undertaken the restructuring of the curriculum so that future graduates from faculties of engineering in particular, and the Universities in general, will be ready to face the challenges posed by the new era of services [17].

The creative way to achieve these is to break down the boundaries between disciplines so that students can have more versatile experiences, taking into cognizance the strengths and capabilities of the programmes across the Universities. A University with strong programmes in so many disciplines such as engineering, business, humanities, science and agriculture has significant opportunities. The integration of the graduates into business environments early in their career development would enable them to demonstrate very quickly their value and potentials and enhance their competitiveness for jobs on a global basis. The T-shaped skills can really be a major differentiator [3].

The T-shape competency profile encourage students to individually develop their skills in the various components during their time in the Universities rather that the "one programme fits all approach". The development and implementation of a T-shaped curriculum is the result of the coordinated efforts of various team-players and should be part of strategic education policy of Universities [4].

Current system of education lacks connection and interaction between different industries, which is something our ageing society will desperately need in the future. People who are talented, professional, caring and full of creative spirit to invent or design products and services for the elderly are needed. The new learning model called 'T-workshop' in higher education uses multidisciplinary approaches to cultivate 
'T-shaped' professionals, elites who interact and cooperate with a wide range of disciplines and fields for the benefit of an aging society. The goal of increasing the communication skills by gathering participants from different backgrounds to solve a problem as a team with some professional helps from the instructors and teaching assistants would be met. This kind of T-shape cultivation would help break down barriers between different professionals and increase the possibilities of multidisciplinary cooperation or interaction. It will also help provide more opportunities and possibilities of a better life for ageing societies of the future [18].

\section{THE NEED FOR NIGERIA TO REFOCUS VOCATIONAL EDUCATION IN THE $21^{\text {ST }}$ CENTURY}

Nigeria like other countries is faced with social and economic problems arising from the deliberate case of neglect and negative attitudes towards vocational and technical educational system [19]. The neglect of vocational and technical education in the country has increased the youth unemployment. The quality of the contributions of these aspects of educational system among Nigerians, especially among the youths cannot be underestimated in the 21st century. Vocational, technical and technological education should be refocused to satisfy the changing needs of people and society. Refocusing of Nigeria's through relevant vocational education programmes will in no distant time make the problem of youth unemployment and poverty among adults become outdated. [20].

The declining industrial performance of the country over the years resulted from the inability to synergise her abundant resources to create an organic productive sector for sustainable development and reduction of wide spread poverty [21]. The availability of competent and dedicated workforce is an antidote to the low-level state of industrialization in Nigeria [22]. Vocational and technical education has the capability to liberate the nation out of the problem of lack of competent and appropriate manpower [23, 24].

Ihinmoyan and Haruna [25] reported the current educational system is deficient in providing the necessary impetus for development. The reforms and restructuring in the educational system to ensure effectiveness and sustainable national development can only be acheived through designing appropriate curriculum and monitoring process with increased funding. All Nigerians must have equal access to vocational and technical education through modular curriculum. To ensure the availability of various categories of workforce, academically sound persons are allowed take all the prescribed modules in area of interest during their further training at a tertiary institution; grow to become a specialist and leader in their chosen professions while other persons are allowed to develop according to their capabilities [22].

\section{NATIONAL UNIVERSITIES COMMISSION (NUC) BENCHMARK MINIMUM ACADEMIC STANDARDS (BMAS) FOR AGRICULTURAL AND BIORESOURCES ENGINEERING PROGRAMME}

The Agricultural and Bioresources Engineering five-year programme curriculum is in compliance with the benchmark minimum academic standards (BMAS) of the National Universities Commission (NUC) [26]. The components of the curriculum are contained in Table 1.

Table 1. Categories of curriculum components

\begin{tabular}{lll}
\hline S/N & Category & Units \\
\hline 1 & General Studies & 16 \\
2 & Basic Science & 26 \\
3 & Basic Engineering & 46 \\
4 & Core Courses & 88 \\
5 & Electives & 12 \\
6 & Student Industrial Work Experience (SIWES/SWEP) & 07 \\
& TOTAL & 195 \\
\hline
\end{tabular}

The Department trains students with broad-based knowledge of various aspects of Agricultural and Bioresources Engineering thereby producing practical-oriented graduates with skills that are needed in mechanized agriculture, storage and processing of agro-resources products and the preservation and conservation of natural and environmental ecosystem.

The objectives of the programme are to:

a. Teach the students the basic physical sciences, applied agricultural sciences and engineering fundamentals. 
b. Allow hands-on laboratory and field practical exercises that will make them tackle challenges on the field.

c. Teach the students the scientific and engineering principles of analysis, design, development and practical work to solving technological problems of agriculture and food production.

d. Train the students to acquire the capability for meaningful result-oriented research in all aspects of agricultural engineering.

Figure 3 illustrates the T-shaped Agricultural Engineer Model.The approach in Figure 3 fosters individuals with a deep technical understanding, the stem of the ' $\mathrm{T}$ ', in the core subjects of the programme coupled with broader knowledge, the top of the ' $\mathrm{T}$ ', in the basic science, fundamentals of engineering, computer technology, engineering design, innovation and creativity, law, management and entrepreneurship, technical report writing and communication and leadership.

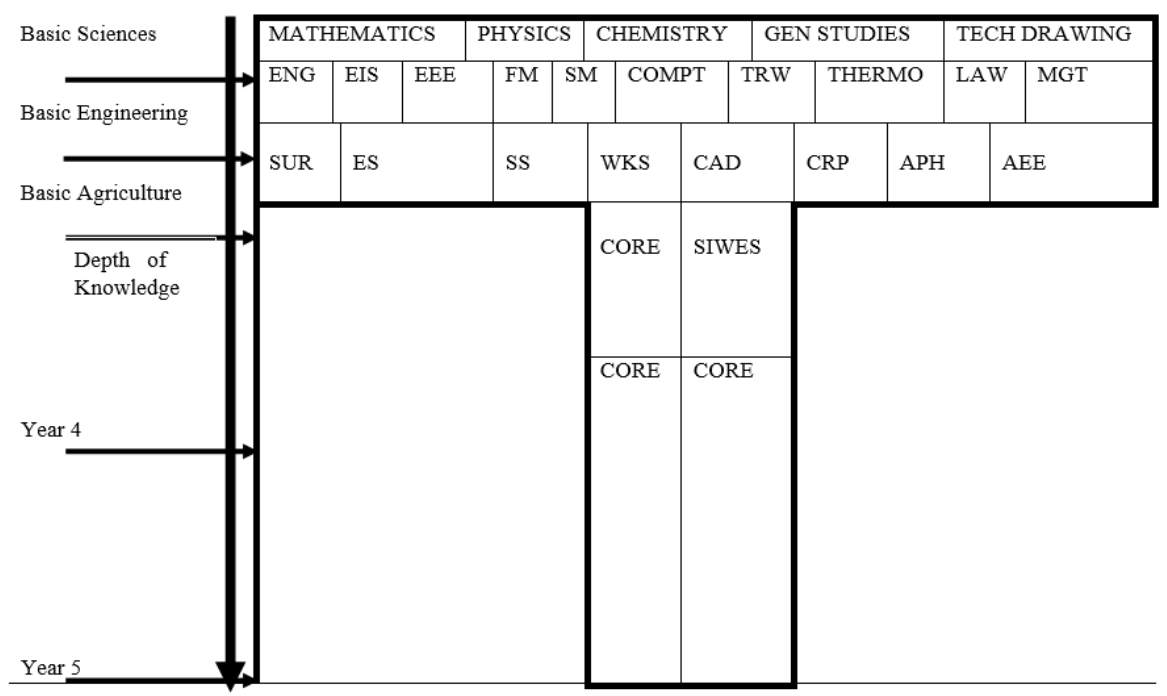

Figure 3. T-Shaped undergraduate programme

KEYS:

ENG-Engineering Mathematics FM-Fluid Mechanics

TRW-Technical Report Writing SUR-Surveying

WKS-Workshop

CRP-Crop Production

SIWES-Students Industrial Work Experience Scheme

EIS-Engineers in Society

SM-Soil Mechanics

THERMO-Thermodynamics

ES-Engineering Statistics

LAW-Law

MGT- Management
EEE-Electrical and Electronics Engineering COMPT-Computer programming

AEE-Agricultural Economics and Extension SS-Soil Science

CAD-Computer Aided Design

APH-Animal Production and Health

The engineering undergraduate curriculum promotes the development of the complete "T". Individuals acquired a breadth of knowledge from undergraduate studies, broader depth of knowledge that will increase their specialization expertise at the Masters level and even deeper at the doctorate level. This approach would result in broad working knowledge, good understanding in specific areas and fosters success in the chosen profession. The T-shaped education allowed for career development and progression through adding layers to expertise and workplace skills for effective leadership [4].

Good understating of mathematics and technology are the known important crucial skills for any engineer. The demand for future engineers and the expectations of employers is growing daily and gap can only be filled through the development of T-shaped skills for a successful career [9].

Companies such as IBM, IDEO, Proctor \& Gamble, Nike and GE all supported the training and recruitment of T-shaped engineering students. The students will be in high demand when they graduate and apply for jobs because they are expected to solve problems in their technical fields within the context of the entire organization to co-create smart solutions [27].

The industries are moving faster than the Universities in the adoption of the T-shaped model. The Universities are to align their curricula to meet up with the growing challenge in the development of their various programmes. Lehigh University training in Integrated Business and Engineering (IBE) programme prepares the students for leadership roles in industrial $R \& D$, entrepreneurial initiatives, 
management consulting, high-tech ventures, innovative technology and financial services [28]. Boston College engineering programme creates the 'societal engineers' with T-shaped skills. The Oregon Universities increased T-shaped learning through the support from the Oregon Engineering and Technology Industry Council (ETIC) investment of \$29 million fund [9].

Engineering education development is shifting from disciplinary thinking to interdisciplinary approaches to remain competitive and produce better engineers in T-shaped skills. The growing gap between engineering education, practice, and research can easily be closed by equipping the qualified engineering students with the T-shaped skills [29]. Industries have great roles to play in accepting to develop these engineering students during their six-month SIWES programme in year 4, accepting them to participate in the National Youth Service Corps (NYSC). Also, after graduation and more important also by contributing to the facilities, Research and Development and training while in school [30].

There are close relations between the companies and our universities. Thus, research programmes are calibrated in relation to the possible need of external recipients of the research and of the doctorates [26]. Our world is changing and changing rapidly. There is need for a 21 st century classroom where the 3 R's (reading, writing and arithmetic) meet the $4 \mathrm{C}$ 's (creativity, critical thinking, communication and collaboration) and all students are prepared to be active participants in our exciting global community $[31,32]$.

\section{CONCLUSION}

T-shaped professionals, especially engineers, are urgently needed to improve performance in rapidly changing knowledge-intensive organizations. Hard work, constant improvements and finding a balance between acquiring general and specific knowledge are major requirements to becoming a strong ' $\mathrm{T}$ ' in life. The transition from University life to the world of work requires substantial attention in the development of various curricula for a better and ideal graduate engineer. The Agricultural and Bioresources Engineering curriculum have the potential to create a T-shaped graduate and future agricultural Engineer.

\section{REFERENCES}

[1] B. Sergio, F. Giacomo, N. Giancarloand S. Marialuisa, "Structure and dynamics of a "T-shaped" knowledge: From individuals to cooperating communities of practice," Service Science, vol. 4, no. 2, pp. 161-180, 2012.

[2] J. Peters, "Educating designers to a T," Design Management Review, vol. 23, no. 4, pp. 62-70, 2012.

[3] Industry Connect, "What industry needs: T-shaped graduates," Accessed Feb2016. Retreived from: http://blogs.oregonstate.edu/industry/

[4] S. Uhlenbrook and E. D. Jong, "T-shaped competency profile for water professionals of the future," Hydrology and Earth System Sciences Discussions, vol. 9, no. 3, pp. 2935-2957, 2012.

[5] D. Guest, "What is a T-shaped skill?" 1991, Retrieved from:http://wordspy.com/index.php?/word=t-shaped Accessed Feb 2016.

[6] K. A. Lawson, R. M. Armstrong, and M. B. Van Der Weyden, "Asearch for a change in Australian Medical Education," Medical Journal of Australia, vol. 169,pp. 653-658, 1998.

[7] N. Donofrio, S. Calline, and J. Spohrer, "Collaborative innovation and service systems: implications for institutions and disciplines," in Holistic Engineering, Edited by Domenico Grasso, 2016.

[8] M.J.C.M. Hertogh, "Infrastructure Renovation," TU Delft Aula. COB-interview (only in Dutch):Bestaande infrastructuur draaiende houden, daar ligt de opgave voor studenten 2013.

[9] B. A. Alabadan and T. M. Samuel, "Competence-driven engineering education: a case for t-shaped engineers," Proceedings of the 6th African Engineering Education Association Conference,pp. 123-130, CUT, FS, Bloemfontein, South Africa, 2016

[10] M. Doyle, "Why engineers need to develop t-shapedskills," 2014 Retreived from: http://blogs.ptc.com/2014/12/03/whyengineers-need-to-develop-t-shaped-skills/\#sthash.HteJ1D9x.dpufAccessed Feb 2016.

[11] B. A. Alabadan, "Educating work-ready T-shaped engineers,'Invited paper presented as Guest Lecturer at the Nigerian Society of Engineers, Ado-Ekiti, Nigeria monthly meeting, Jun 2016.

[12] T. Hanekom, "Curriculum review from the dual prism of academia and industry," Proceedings of the 6th African Engineering Education Association Conference, pp. 212-218, CUT, FS, Bloemfontein, South Africa, 2016.

[13] M. Havenga,"Engineering education for sustainable development: embedded skills in problem-based projectorganized learning," Proceedings of the 6th African Engineering Education Association Conference, pp. 105-110, CUT, FS, Bloemfontein, South Africa, 2016.

[14] C. A. Sanchez, B. L. Ruddell, R. Schiesser and V. Merwade, "Enhancing the T-shaped learning profile when teaching hydrology using data, modeling and visualization activities," Hydrology and Earth System Sciences Discussions, vol.12, no. 7, pp. 6327-6350, Jul 2015.

[15] UK Royal Society, "Hidden Wealth: Science in Service Sector Innovation,” 2009. 
[16] IfM and IBM, "Succeeding through service innovation: A service perspective for education, research, business and government," Cambridge, United Kingdom: University of Cambridge Institute for Manufacturing. ISBN: 978-1902546-65-0, 2008.

[17] M. Mukhtar, Y. Yahya, S. Abdullah, A. Hamdan, A. N. Jailani, and Z. Abdullah, "Employability and service science: Facing the challenges via curriculum design and restructuring," Proceedings of the International Conference on Electrical Engineering and Informatics ICEEI'09,IEEE, vol. 2, pp. 357-361, 2009.

[18] S. C. Kang, P. L. Liu, Y. F. Lee, S. R. Ye, H. R. Yang, and C. W. Peng, "The teaching method of multidisciplinary T workshops: A new teaching model for an aging society," Gerontechnology, vol. 13, no. 2, pp. 101-102, 2014.

[19] N. D. Mbanefoh, and O. A. Bamiro, "Training for effective implementation of the pre-vocational aspect of the new policy on education," In T. I. Eze and M. A. Madusolumuo (Eds.), Third World Strategies for Technological Development, pp.148-156, Onitsha, Nigeria: Summer Educational Publishers Limited. 1990.

[20] C. C. Calhoun and A. V. Finch, "Vocational education: Concepts and operations," (2 ${ }^{\text {nd }}$ Ed. $)$, Belmont, California, USA: Wadsworth, Inc. 1982.

[21] G. Adefaye, "Neglect of technical, vocational education increases youth unemployment,"Vanguard,pp.30, 2004.

[22] B. M. Ndomi, "Mechanisms for improving the skill content of the curriculum for technical college agro-mechanics trades in Gombe State," Unpublished Master's thesis, University of Nigeria, Nsukka, 1998.

[23] USA's Advisory Council on Vocational Education, "Vocational education: the bridge between man and his work," U.S Department of health, education and welfare, office of education. Washington D.C.; Government Printing Office, 1968.

[24] M. A. Garuba, F. E. Agweda, and D. I.Abumere, "The contribution of science and technology education to national development: The Nigerian experience," Journal of Education and Practice, vol. 3, no. 1, pp. 16-22, 2012.

[25] T. Ihinmoyan and S. Haruna, "Entrepreneurship education in Nigeria: A tool for socio-economic development," Advances in Management (A Journal of Department of Business Administration, University of Ilorin, Ilorin, Nigeria.), vol. 10, no. 1, pp. 17-28, 2012.

[26] NUC, "National Universities Commission (NUC) Benchmark Minimum Academic Standards (BMAS) for undergraduate Programme in Nigerian Universities (Engineering and Technology) 2007-04," 2014.

[27] B. Dunn, "Engineering and business a combination for success." Retreived from: https://www.asme.org/careereducation/articles/teachers-academics/engineering-and-business-a-combination-for-success. 2014.

[28] M. Lih, "Making engineering education moreT-shaped," In: Doyle M. (2014): Why Engineers Need To Develop TShaped Skills, 2014. Retreived from: http://blogs.ptc.com/2014/12/03/why-engineers-need-to-develop-t-shapedskills/\#sthash.HteJ1D9x.dpuf

[29] P. M. Gerson, and B. Ramond, "Educating great T-shaped engineers," International Conference on Engineering and Product Design Education, 13-14 Sep 2007, Northumbria University, Newcastle Upon Tyne, United Kingdom2007.

[30] L. Borrell-Damian, T. Brown, A. Dearing, J. Font, S. Hagen, J. Metcalfe, and J. Smith, "Collaborative doctoral education: University-industry partnerships for enhancing knowledge exchange," Higher Education Policy, vol. 23, no. 4, pp. 493-514, 2010.

[31] M. Kolk, "The $21^{\text {st }}$ century classroom-where the 3 R's meet the 4 C's!," 2011. Retreived from: http://web.tech4learning.com/blog-0/bid/45149.

[32] A. H. Dunn, B. Sondel and H.C. Baggett, "I don't want to come out as pushing an agenda: How contexts shaped teachers' pedagogy in the days after the 2016 U.S. presidential election," American Educational Research Journal, vol. 56, no. 2, pp. 444-476, 2019. 